\title{
Factors that Affect the Derivatives Usage of Non- Financial Listed Firms of Pakistan to Hedge Foreign Exchange Exposure
}

\author{
Numan $\operatorname{Khan}^{1}$ \\ Khurshid Ali ${ }^{2}$ \\ Alina Kiran ${ }^{3}$ \\ Riaqa Mubeen ${ }^{4}$ \\ Zeeshan Khan ${ }^{5}$ \\ Nasir Ali ${ }^{6}$ \\ ${ }^{t}$ National College of Business Administration and Economics (NCBAE ${ }^{2}$ ) \\ Salford University Manchester, UK \\ ${ }^{3}$ Lecturer at Bahria University Islamabad \\ Graduate from University of Agriculture, Faisalabad, Pakistan \\ ${ }^{5}$ Pakistan Institute of Development Economics (PIDE) \\ ${ }^{6}$ COMSATS Institute of Information Technology, Islamabad
}

( $₫$ Corresponding Author)

(D) Check for updates

\begin{abstract}
This study aims to investigate the factors that affect the derivatives usage of non-financial listed firms of Pakistan to hedge foreign exchange exposure by using data of 51 non-financial firms listed on Pakistan stock exchange from 2010-2013. The dependent variable was derivative usage which was used as dummy since no financial information was disclosed in company annual reports but the decision of usage or not. Non-parametric tests were uses which is univariate analysis to calculate the mean difference between users and non-users of derivative usage for hedging purposes. Further, logistic regression model was used to analyze the impact of financial distress costs, tax convexity, underinvestment problem, profitability, managerial holdings of the company and foreign sales on firm's decision to whether they use FX derivatives for hedging purposes or not. The result shows that financially distressed firms, having lower managerial holdings and lower interest coverage ration with high foreign sales are using FX derivatives in Pakistan.
\end{abstract}

Keywords: Foreign exchange exposure, Hedging, Pakistan stock exchange.

JEL Classification: Goo, G31.

\section{Introduction}

Business in today's world is increasing with great pace. Globalization is also playing its role in the business. Firms across the world is earning profitability as well as gaining competitive advantage. Nevertheless, the companies are also facing financial risks who have opened most of the businesses internationally. These risks may hurt the cash flows of the firm or reduce them. The companies tend to reduce the variability's in their cash flows use corporate risk management techniques. Miller and Modigliani (1958) however, introduced a concept which was the theory of irrelevance, stated that with the investment policy which is fixed and there is no contracting costs or taxes, then no need to use corporate financing policy is irrelevant. Miller and Modigliani (1958) about their theory was right, that there is no such need for hedging and the shareholders and companies can use diversification or diversify their portfolios to reduce the variability or the expected risks in their investments. Notwithstanding, the considerable literature is available which opposes the former for his theory, Smith and Stulz (1985); Bessembinder and Seguin (1990) proposed that the former theory could only be implemented if the markets are perfect and there is no asymmetry of information and expected volatility in the markets.

The increase of the investments of firms and individuals in countries other than their own have considerably increased their competitive advantage and also taking benefit from the economies of scale which is available through cheap labor and materials. The new emerging markets in developing countries have increased the profitability of the firms on one hand but also the substantial variability in the net income because of the cash flows variability. Stake holders especially the agents of multinational firms are focusing and determining the corporate risk management techniques to reduce their variability from cash flows which are hurting the companies' profits.

Financial risks (Foreign Exchange risk) are absolutely important when the companies have foreign operations. The unpredictability in the firms' sales level, the unwanted movements are the great causes due to which the companies hedge their operations abroad. Corporations are using FX derivatives to reduce the volatility in their operations and their exposure to such investments. The corporations mostly use these FX derivatives to reduce the financial distress costs because there is positive relation between them which was not accepted by other countries 
till 2008 global crisis. Most of the managers in different developing countries believe that our operations abroad have face exposure because of the different trade agreements with foreign countries as well as the reduction or fading away of the restrictions on capital flows have increased the FX exposure for firms. Hedging thus become an important factor for managers of multinational companies to cover their foreign exchange risk positions.

Corporate Risk management can be implemented in many ways such as forwards, futures, Swaps and options and risk management at the firm level only manages Exchange rate Risk. Classical and Neo Classical research shows that hedging cannot increase firm value and it was called "the theory of irrelevance", However, the recent studies on hedging shows that capital market imperfections which includes agency costs, Financial distress costs and direct and indirect costs of bankruptcy, costs of taxes and costs related to underinvestment opportunities, hedging may reduce these expected costs, by covering the uncovered positions and which will ultimately increase the wealth of shareholders or value of the firm. It is also proved from the previous studies that how the corporate risk management in general and hedging in particular can play a role in the maximization of wealth of shareholders.

It is also provided that corporate risk management reduces the different costs related to firm and reduce the variability in the cash flows can leads to the wealth maximization. Costs of Agency Conflicts, Assets Substitution, Underinvestment problem, or a dysfunctional managerial behavior resulting from under diversification, or noneffective incentive structures, External financing costs and financial distress costs by increasing investments and aligning the corporate risk management techniques (Aretz et al., 2007).

A definition of Hedging: When a firm takes an opposite position to their assets and liabilities to reduce its volatility in cash flows by using corporate risk management techniques. A firm uses an off balance sheet instruments to hedge a particular position by using forwards, futures, swaps and options for currencies, commodities, interest rates and other assets. A firm can hedge via other sources such as by restructuring the capital in balance sheet which also has possibility. A firm can reduces the debt to equity ratio which will reduce the burden of cost of capital on the firm but it can reduce the benefit of the tax shield as well as the incentives of the firms' increased tax liability. Moreover, the firms can also hedge by offering preferred stocks or convertible bonds, when at the time of distress a firm can just stop the dividend payments or interest rates to the bondholders (Smith and Stulz, 1985). Hedging is necessary for a firm to cover its exposure. It can also be covered by investing in a less risky assets or by imposing a dividend restrictions or choosing private debt which is less costly, all these alternatives can be used for hedging. Why hedging is necessary remained a most important question for Managers (Agents) of the firm.

Underinvestment problem is when the equity holders or managers don't want to invest in a positive NPV projects and not letting benefit the bondholders of the company. Bond holders protect themselves whenever the shareholders are being opportunistic, the former offers lower price for a firms bond which increases the company cost of capital. By encouraging and assuring bondholders to pay more, the firm must have to make them convince by either of the two things, that the wealth transfers will not take place either by covenants or hedging Bessembinder (1991). The choices and alternative projects for investment of firms can create a conflict between bond holders and shareholders. Myers (1977) explain this phenomenon about the future expected investment opportunities that with potential investment opportunities, there is a fixed capital structure, and the fixed claimant, taking a Net positive value projects can reduce the wealth of the shareholders which will transfer most of the wealth to the bondholders, which shareholders in turn, can't take it by behaving opportunistically. Myers proved this theory to be the underinvestment problem. By reducing this problem, the firms with more positive investment opportunity sets are aiming to hedge to reduce the firms' variability in the cash flows. The more debt taken by the firm articulates the higher the investment problem, thus it shows the more debt in the firms' capital structure which means firms' with more leverage are going to use corporate risk management techniques or hedging. The hedging usually shifts the individual future position of default to non-default results, which makes the equity holders tend to future states of non-default. Both the bondholders and equity holders can get their returns without any conflict in between them or agency costs is there.

Taxes are also one of the risk when it is in the convex schedule. Progressivity in taxes are not good for company when it is not capable of dealing with it. Most of the times firms' carry forward it to next year but still it becomes a problem for because of the statutory convex schedule which has made by the government. But Smith and Stulz (1985) and Mayers and Smith (1982) argued that in fact hedging can reduce the tax liability. They further concluded that it is the variability which could be actually reduced in the income by the firm through corporate management techniques. To see how it is done is, For example: A firm is going either going to lose or earn $\$$ 500,000 or earn $\$ 500,000$, and the firm will pay $25 \%$ of its tax, which is without hedging, even if the expected income is zero. The firm is expected to pay $\$ 19000$ in taxes. At this very level if the firm can hedge to eliminate the income volatility, which is expected income and taxes are zero. This example shows congruence of how the tax losses can be carried forward which reduces the tax convexity but it shows the tax convexity can provide the benefit to hedge. Thus, they concluded that whenever the tax is of convex schedule of an organization or a firm, means when the income increases, the tax also increases, then the firm can reduce the volatility of the pre-tax income in order to mitigate the tax burden (Graham and Smith, 1999). Moreover, It is also been proved that the firm tax schedule will not always be convex due to the pre-tax income. It can also be via the limitations of the special tax preference, for example, for an unlimited number of years when the firm is unable to carry forward its losses or carry backward its losses. Thus firms may be unable to exploit these benefits which is because of low income or losses.

Bankruptcy of a firm lasts till the firm assets are transfer, when it happens, in a perfect market world, then there left a costless negotiation of the firms' possessions. The wealth of the firms' generally transfers from residual claim holders to bondholders. Moreover, the bankruptcy costs or the expected bankruptcy in the future can create huge costs for the firm which creates a negative impact on the firm value (Smith and Stulz, 1985).

Moreover, the corporations are induced by the costs of bankruptcy to hedge. Most of the times the highly leverage firms which pay taxes and also the interest and principal amounts to its bondholders, when the firm value is below the face value of the firm at the time of maturity, the bondholders receive lesser amount because of the 
bankruptcy costs occurred. Nevertheless, the shareholders of the firm are paid even lesser than the bondholders. Hedging is the only way out for the firm to reduce the expected variability in the cash flows of firm and therefore the incurrence of bankruptcy costs of the firm which ultimately benefits both the shareholders and bondholders (Smith and Stulz, 1985). The bankruptcy costs are consist of two types. The first one is direct costs which is related to the proceedings of the bankruptcy and which occurs directly, such as the fees of lawyers, expert fees, accounting fees and administrative fees. While the second cost which is indirect cost of financial distress is related to firm which occurs in a large absolute value of the firm Gruber and Warner (1977); Weiss (1990) are of the view that it occurs usually only 1-3 percent of total firm value. There are also some other costs which are related to the firms' bankruptcy and which is not directly related to the firm but it is a kind of psychological impact costs. These are when the firm stakeholders perceive inability of a firm to go on further, where the customers and suppliers cannot be ensured that credits which are still accrued shall be settled, warranties must be fulfilled, the resources are available etc. the credit rating of firm, the distraction of management, the huge turnover of employees and then recruiting and hiring, then training and development of employees can create a huge costs. The empirical review of Cutler et al. (1989). Believe that indirect costs of a firm are way much larger than the direct costs, because it can leads to 20 percent of the firm value.

It is to be understood that the future costs of financial distress, are certainly increase when the leverage and fluctuations in a cash flow, these factors leads to bankruptcy of the firm in future. This shows that when the leverage and volatility in cash flows increase, the firm value decreases and which ultimately goes toward the bankruptcy. For this purpose, the corporations adhere to the corporate risk management techniques, through which the firm value increases by reducing actually the fluctuations in the cash flows and hedging the leverage Rawls and Smithson (1990); Mayers and Smith (1982); Dolde (1993) and Lang and Stulz (1992).

To reduce the conflicts of interest between managers (agents) and the Shareholders (principals), the companies try to make parallel their interests by many compensation plans. It ranges from upper management remuneration to stock options or company's stocks. Companies tie managers' performance or their remuneration with the company's stock price. So however the company's perform, if the company's stock prices plummet in the market, the remuneration of the managers also go down with it. These kind of stock price related compensation plans affect manager's performance and also the level of their intensification, which leads to the increment of the managers risk aversion of these undiversified managers. If these kind of compensation go on in the company, the managers won't diversify or take risk for the company's improvement. There is another kind of plan via which a company if offers a stock option features, which is related to the performance of managers by increasing in the stock price will increase the stock prices of theirs which is a lot better. It will help the managers to boost up the company's performance as well as will mitigate the risk aversion level of managers (Bartram, 2000). This was without the hedging solution and only the risks which are somehow in control of the managers of the company.

There are some kind of risks which cannot be reduce by the managers of the company or it is beyond the control of the management. Therefore, the stock price cannot be a good indicator of a company in the absence of hedging. The management performance thus cannot be measured that much easily. Hence, the companies influenced by the unrelated risks which are beyond the control of the management on the stock price, here the compensation plans play a role which is very less effective. It is also flawed that it at times reward poorly performing managers while punish good performing managers. Corporate Risk management techniques, however, can mitigate the influence of separate financial risks on firm value and thus reinforce the relationship between stock price and managerial performance. And finally it will also be concluded that who is the good performing or efficient and poorly performing or inefficient managers (Campbell and Kracaw, 1987).

The other reasons include Coordinating financing and investment policies (i.e. when a firm has to bear the additional costs because of the shortages or surpluses of funds, because the cash flows of the firms vary over time and the firm might ordained the positive NPV projects or the costs of high external financing. So to hedge these costs is necessary), Foreign sales (when import and exports are high of firm and the exchange rate is not that stable, then managers of the firm has to hedge the risk which is necessary for the stable cash flows of the company), the asset substitution problem which is also important which needs reduction and that is possible through hedging because managers shift the riskier projects to bondholders when the value of the firm is low and the consequences are faced by the bondholders, along with that the another reason is the undiversified managers which is through the way of idiosyncratic risk, the managers of the company do not want to mitigate it while the shareholders of the company try to reduce it or hedge to decrease the risk and increase the wealth of the shareholders. This happens due to the fact that some undiversified managers engage in a conglomerate mergers or suboptimal which reduces the risk of the investment of the managers while increase the risk for shareholders. So the corporate risk management can reduce the level of agency costs and reduce the undiversified level of risk management.

Since 1970's, the oil import risks and other risks have deteriorated the situation which increased the demand for firms to hedge the financial risks in the market in order to increase the pre-tax income of the firm. Hedging is important for developed as well as developing countries. In developed countries, corporate risk management instruments markets are well established but in developing countries, it is not. Some countries have over the counter derivative markets like Pakistan while some have organized exchange but it is still in the development phase. The Asian crisis in 1998 had a huge impact on the companies in Asia, mostly multinational companies and national companies in Asia face severe Financial risks which were depreciating currency and instability in the ecopolitical environment which represents the country and economic risks. Though these companies have the advantage to save themselves through the lower labor cost and imperfect competitive markets in Asia. Hedging was not that much introduced and therefore losses were severe in the market. Same is the case in Pakistan, where the report of Securities \& Exchange Commission of Pakistan (SECP) (2006) shows that Karachi stock exchange has remained the top most unstable market. The stock price volatility in the market shows the risk of securities in the market. The causes which were identified in this case was non-standard practices, the carry over transactions (COT-Badla). These reasons ultimately leads to the excessive volatility of the stock market which consequentially ends up in investor losses, market manipulation and speculation. Moreover, SECP (2006) documented that there is a strong need for hedging instruments in the market, otherwise, the Continuous funding system which is the only 
way for investors, A leverage system like CFS in the market increase dependence which is not good for investors and institutions. The inevitable need for the derivative instruments which will offer price discovery, downside protection to investors and mitigate the dependence on the continuous funding system. It is also believed that the introduction of derivative products, in this kind of developing market, not only provide many risk reduction opportunities but also channel more capital, players, products, and Foreign direct investment (FDI) to the developing market.

SECP (2006) identified many rules and recommendations for the Exchange traded derivatives, they are following.

- The Pakistani market of derivatives is currently emerging, however, Proper governance and good infrastructure is really important.

- A capital adequacy for the exchange, A clearing of transactions and Clearing house is one of the most important need for the FX derivatives

- Exchange traded Derivatives (ETDs) whether it is trading at an existing exchange or at a new exchange should provide an environment where all investors invest freely and easily.

- ETDs when they are developing in the emerging markets will align the stake holders and abolish the conflicts of interest.

- There must be enough lawful, monitoring and Governance infrastructure and supervision.

- There should be an easy procedure from SECP in the form of open licensing for exchanges which are new or existing exchanges, so that they can easily meet the criteria, which can comply and qualify for derivatives trading.

- Self-governing market and member examination.

- Active application by SRO and APEX supervisory body.

- There must be efficiency and independence via licensing and registration for the market parties, they should be closely supervised for the capital adequacy, professional proficiency and the business standards and conducts.

If we look into the State bank of Pakistan (SBP) report, from 2010 to 2015, the exports and imports of Pakistani economy is respectively, the increase in across the borders trade due to globalization has also increased the exchange rate risk which is also one of the main concern of multinational and national companies. The risk cannot be reduced just by improving efficiency or economies of scale in the production. It is a kind of risk which is beyond the control of management. Firms at different stages and its management also comprehend the idea that it is inevitable to manage the risk of foreign exchange at this early level. Thus there is a dire need to reduce the Foreign exchange risk by using different hedging or corporate risk management techniques at this level which is important for firm as well as for shareholders. There are techniques available in Pakistan through which the firms' deal with the mitigation of the foreign exchange rate risk. It is to be taken into account that till now, no exchange traded derivatives markets are present in Pakistan. Thus, the corporations dealing mostly in foreign operations tend towards the usage of over-the-counter market derivatives for the purpose of hedging their foreign exchange exposure.

The current empirical literature has engrossed upon the scrutinizing of the factors, which are internal and external, endogenous and exogenous, which has impact on the firms' decision to hedge Foreign exchange Exposure (Smith and Stulz, 1985; Jalilvand, 1999; Haushalter, 2000); Mian (1996) and Guay and Kothari (2003).

The issue of the usage of derivatives especially for the purpose of hedging is well explored in the developed world as can be seen from the work by smith and Stulz, mayers and Smithson but it is not fully explored or yet to be explored in the developing and third world countries. The issue was highlighted at first in Pakistan by the Afza and Alam (2011) in which the data was collected between 2004-2007 which was an old one. After the global crisis improvements which are made are not fully explored in this regard. The key objective of this study is to identify the factors which affects the firms decision to use derivatives for the time period of 2010 to 2013.

\section{Literature Review}

Corporations and its shareholders usually use diversified portfolios, mutual funds and proliferation of techniques to mitigate risk in their investments. Risk Management of investments by shareholders has mostly been through via diversified portfolios or low risky investments. Most of the researchers hold on to the idea that risk management can also be reduced through the use of derivative instruments which certainly minimize the firm risk exposure. It is a matter of risk the stake holders especially the shareholders want to minimize through diversification. Two risks which is mostly associated with firm is business risk and financial risk. Business risk is associated with the company operations, inputs and technological factors. This risk is impossible to hedge as it is strongly aligned with the firm competitive advantage as well as the firm shouldn't want to hedge it. Financial risk is somewhat external risk and it is strongly recommended that it should be hedged when the firm is involved in international operations. Exchange rate risk, interest rate risk and currency risk is constituted in financial risk.

\subsection{Empirical Review}

Considering Miller and Modigliani (1958) suggest that corporations can reduce the risk by different methods under the perfect capital market conditions and no use of derivatives to mitigate/reduce risk. By reducing risk through buying oil contracts and options and selling them by corporations will not alter the company value, Since the individual investors in the company can buy and sell options by themselves if they care about such exposure. They can adjust such exposure by themselves and the corporations are in no need to buy and sell options for hedging.

In contrast, there are many rationales for a firm provided by the researchers which shows that why a firm might wish to hedge. Stulz (1984) and Lessard (1990) in investing and Financing decisions there is a strong need of corporate risk management (Hedging) when Stake holders of a corporation which are bondholders, shareholders, managers, employees will lack congruence when there is lack of information or asymmetries of information exist, a 
firm is highly leveraged, firms with high risk debt and not high profitability of a firm and underinvestment problem, tax convexity, financial distress costs, bankruptcy costs and agency costs.

Aretz et al. (2007) on Why hedge? Rationales for hedging and value implications with a substantial evidence that in a capital market imperfections, corporations apt to increase the firm value by using hedging techniques. The value increases when the firms reduce the costs which arise from agency conflicts, financial distress or bankruptcy, average tax burden and external financing. They proved it empirically through many theories that there is strong backup of corporate risk management in increasing the value of shareholder wealth. By analyzing the discussed theories they found that reducing costs of the underinvestment problem and asset substitution problem via hedging is possible because it may reduce the cash flows volatility and when there is such gentle decrease in the cash flows, the underinvestment problems itself mitigates. Hedging can also play role in the alleviating the cash flows fluctuations which leads to mitigate the future financial distress costs and bankruptcy costs.

Froot et al. (1993) on the investment and financing decisions in relation to hedging policies of firms ascertained that firms can be capitalized on the use of derivatives when the externally generated funds are more costly than the internally generated funds. Firms can be beneficial at this stage because the variations in the externally generated funds are hedged and the sufficient internally generated funds are available for corporation's investment. Secondly, they proved that firms will hedge less when it is certain that there is high correlation between cash flows and future investment opportunities. Thirdly, they substantiated that multinational firms have hedging strategies which depend on other number of considerations as well. It includes the interest rate exposure as well as they hedge so as to "lock" a specific amount of investment in a specific country.

According to DaDalt et al. (2002) had proved by getting results on 486 non-financial firms of USA over the period of 1993-1995 that firms with enhanced investment opportunities, they will use higher derivatives along with when they have lower cash stocks. They also found that firms investment expenditures when negatively correlated with firms' internal cash flows, the derivatives usage will be higher. They mathematically proved that firms with underinvestment problem, high growth opportunities and external financing is costly than the opportunity cost of internal financing, then the use of derivatives will become higher.

Graham and Rogers (2002) on Tax incentives and hedging proved that firms hedge to increase liability while gain interest tax deductions. Postulating his results on 442 non-financial companies, they found similarly to the previous literature that firms hedge for tax incentives (Mayers and Smith, 1990) that corporations reduce the volatility in cash flows of debts and also reduce the interest taxation, While not in line with the smith that firms also hedge when there is a tax convexity. The results shows that corporations don't most of the times hedge for tax convexity but use accounting policies or carry forward the losses in least way.

Borokhovich et al. (2004) documented a study on the board composition and derivatives usage on 284 nonfinancial US firms. Borokhovich et al. (2004) suggested that the role of board of directors (outside) is positive with hedging, i.e. there is a positive relationship between derivative usage for debt and outside board of directors. The coefficient of size of directors in the firm is consistent with the theory of derivative usage. The results show that managers and inside board of directors will not use risk management derivatives because they are risk averse and will not use such techniques. The under investment problem showed no relationship with the board composition and also the tax convexity variable was not included.

Another type of explanation of corporate risk management is given by Bessembinder (1991) that hedging is the way through which corporations can increase firm value. The traditional methods where it is been said by Modigliani that no contingent contracts can alter firm value. Bessembinder (1991) suggested that with investing in forwards and futures, we reduce such incentives to under invest. Moreover, there are two reasons which he found out that corporations not individual investors do hedging for two reasons. The one is agency costs which is increase the future states of default into non default. And also to balance such conflicts through hedging between debtors and creditors and to reduce the incentive to underinvest for equity holders. The second reason is that of independent of investments. Hedging increases bonding terms with external stake holders by its value changes in the commitments and also the net cash flows are positive where it is low.

Purnanandam (2008) on financial distress and corporate management, suggested that there is positive relationship between financial distress firms and corporate risk activities. His study was based on 3000 U.S. nonfinancial firms with a cross sectional analysis. He further concluded that leverage and hedging have non-monotonic relationship for high market to book value firms, His model further predicted that there is a positive relationship between hedging and leverage for moderate corporations while there is a weak relationship between hedging and leverage for highly leveraged firms. Moreover, he documented that large and small firm's hedge for different reasons while the hedging for both groups is similar for financial distress costs.

Mian (1996) on the evidence of corporate hedging policy determined, Mian (1996) resulted on the basis of the 3022 firms, out of 771 firms as hedgers, 543 were those firms which share the information regarding hedging and 228 firms report use of derivatives but no information is provided on hedging by these corporations. He drew the following conclusions that there is no relationship between hedging and financial distress costs, mixed evidence with tax convexity progressive schedule, financial contracting costs and capital market imperfections and strong evidence is present between hedging and firm economies of scale.

Horng and Wei (1999) on the use of derivatives in the real estate investment trust (RIET) industry concluded that corporation's up to 41 percent use derivatives, along with that tax considerations and speculations are of no considerations here because RIET has tax advantage and speculations are regulated in this industry. Nevertheless, they further concluded that Larger RIETs and mortgage RIETs are using more derivatives. Smaller RIETs with high debt, Strong evidence for Financial distress costs and entry costs are using more likely to use derivatives for hedging. They further found mixed evidence on market to book ratio which means there is weak relationship between Market to book ratio and derivative usage. Mortgage RIETs also increase hedging when interest rates decreases.

From the currency point of view the corporate risk management is somehow related to what is the contingent contracts which is used for hedging. 
Schiozer and Saito (2009) investigated the determinants of currency risk management in Latin American nonfinancial firms. The panel from 2001-2004 data was selected for these firms to attain the results. The results indicate that derivatives which is held for hedging purposes give in return the same cash flows of magnitude of setup costs, expected financial expenses and financial expenditures. They only do not scrutinized the decision to keep derivatives but also the magnitude of why to keep derivatives in the firm or why to invest in it and also the operational hedging significance in the risk management strategies. They also concluded that, Economies of scale and Bankruptcy costs or financial distress costs, Asymmetric information and growth opportunities are important for firms' decision of risk management and it is also determined that firms not alone just hedge for tax benefits.

Howton and Perfect (1998) Currency and interest rate derivatives in U.S. firms, examine a sample of 451 fortune 500 companies, S\&P 500 and 461 firms were selected randomly. They concluded that $61 \%$ firms from S\&P and fortune 500 and $36 \%$ of randomly selected companies are consist of derivative usage. In their research, they also found out that swaps are used most frequently for interest rate contract, while forwards and futures are the most frequent use of currency contracts. They further suggested that the definitions used by the firms for these contracts are different across the sample as well as the determinants due to which the derivatives are use are also different for most of the firms and they are mostly stable with theory. The one exception in that the firms which were selected as random in sample, their firms' derivative use and theoretical determinants are not strappingly correlated.

Haushalter (2000) investigates the hedging policies of oil and gas producers between 1992-1994 where he determined the extent of hedging related to financing costs. He found out that companies will use more derivatives which have greater financial leverage than those which are not. He also found out that hedging instruments and hedging costs are more likely related to economies of scale. Moreover, the companies with larger size and those companies whose productions are located in those areas where prices are correlated with the prices of derivatives which are based are more likely are the companies who manage risks.

Nguyen and Faff (2003) on the determinants of derivative usage by Australian companies, Nguyen and Faff (2003) scrutinized 469/year observations of firms from 1999-2000, based on two questions i.e. the decisions to use derivatives and to the extent to use it. They concluded that larger firms are more likely to use derivatives because of its setup costs. Furthermore, they concluded that once the decision to use the derivatives is made, the firm is going to use it when its leverage is going to increase. The overall results focus on the firms' wealth maximization rather to increase the wealth of managers. They also documented that the corporations mostly articulate the derivative policies for the reduction of expected financial distress costs and also to manage the expected cash flows to the organization. However, the result on underinvestment problem was found mixed in their research.

Fok et al. (1997) determinants of corporate hedging and derivatives, they found that hedging reduces the expected volatility in cash flows, as well as reduces the financial distress cost, agency costs of external financing, and some costs of equity. Moreover, they concluded that there is no relationship of increase in firm value by when tax liability is reduced. Furthermore, Corporate hedging affect the decision of corporate ownership, the larger the firm, the higher the hedging, with larger percentage is derived from growth opportunities and convertible debt can also be served as an alternative for corporate hedging.

Similarly, Géczy et al. (1997) on the Use of currency derivatives by firms, examined some similar variables to the previous literature, they concluded that firms with greater growth opportunities and tight financial constraints are more likely to use currency derivatives for hedging. The results also suggested that firms are prevented sometimes to invest in growth opportunities which are valuable, in this case firms to remove this barricade for the reduction of this issue, firms use derivatives in this regard which reduces the cash flow variation.

Kedia and Mozumdar (2003) on another side, the foreign currency-denominated debt, they scrutinized the determinants of debt which is issued in 10 major currencies by large U.S. firms. The fraction of subsidiaries across the world of many companies, they resulted that the foreign currency is issued by firms to hedge their exposure at both level whether it is at aggregate or individual level. They also found strong evidence that firms choose those currencies in which there is low asymmetry of information between domestic and foreign investors.

Jalilvand (1999) examined the differences of firms those derivatives that how differently Canadian non-financial firms use derivatives. They found that scale of firms, operational efficiency, and level of integration treasury activities were found to be the important determinants for identifying the Canadian users and international users of derivatives. It is also suggested that Canadian users have lower credit ratings and also consist of high leverage than non-users. There is also a positive relationship between maturity of debt and derivatives usage, providing the fact that to reduce the effect which are adverse in nature which is to transfer wealth from shareholders to bondholders. He also found weak evidence for tax benefits and also found no evidence for managerial risk aversion and ownership concentration which is used for influence of the corporate usage of derivatives in Canada.

The previous literature documented so far is based on developed countries. It comprehensively described how the national and multinationals, use derivatives (such as Swaps, Futures, Forwards, options and Interest and Currency derivatives), for hedging or corporate risk management. A limited data on a focused topic can be found in the Asian markets. Some of them taken into considerations the factors affecting derivatives like Muller and Verschoor (2007) examined the area of Asian foreign exchange exposure where the authors selected 3,436 firms to determine the relationship of operating characteristics of Asian firms with the foreign exchange exposure. They concluded that 25 percent of the firms are getting exposure effects to U.S dollar and 22.5 percent of firms experienced an economically significant exposure to a Japanese yen during the period of 1993-1995. Moreover, the authors concluded that the rate of significant exposure depends on the size of the firm and a return horizons. It varies with return horizons, the short term exposures should be well hedged while the long term exposures may found significant risk. They also found out that there is a negative impact of liquidity and leverage, in contrast to the U.S. Findings, on Foreign exchange risk but a positive impact of size and dividend payout ratio.

Fazillah et al. (2008) used a two stage regression model to find out the relationship of derivatives with corporate structure and its operations. They take into account 101 Malaysian listed non-financial companies from 2001-2005. They concluded that there is a simultaneous relationship between hedging and corporate structure. Same as Smith and Stulz (1985) they resulted that financial distress costs, and other costs are reduced through 
hedging while the external debt capacity increases when the firm is involved in hedging. Tax convex schedule is also be beneficial for firms, the way the company will take more debt to gain the potential benefits of tax on it, however, the financial distress costs will increase but the firm is going to increase the hedging in this regard which is still beneficial for the firm.

Afza and Alam (2011) worked on factors affecting firms' decisions to use derivatives. The only case study from Pakistan in which over the counter market was analyzed for hedging purposes. They use the data of 86 nonfinancial firms listed on Karachi stock exchange for the period of 2004-2007. In this research, due to information constraints, they use binary variable for derivative usage instead of notional value or fair value of derivative usage. They operated different models to gain results such as non-parametric was used to identify the users and non-users operating characteristics. Logit model was used to determine the impact of factors that affects the firms' decision to use derivatives for hedging. The findings were that those firms who have higher foreign sales may use derivatives in higher terms. Moreover, financially distressed firms and large size firms, financial constrained firms and those firms who have fewer managerial holdings are more likely to use Foreign exchange derivatives for hedging. They further suggest that the amateur derivative market in Pakistan, it is preferred that the investment should aligned to the derivatives market to hedge in order to reduce the expected costs of debts, costs of equity and financial constraints.

\subsection{Theoretical Review}

Derivatives play its role in many ways in both hedging and speculation. The concern of this thesis is with the derivatives which are used for hedging and as a tool for corporate risk management. Mixed approach has been followed on the derivatives usage and many theories have been proposed on it. Smith and Stulz (1985) proposed a different view on this by rejecting (Miller and Modigliani, 1958) by asserting that Derivatives do play role in the firm to hedge its different risks internally and externally.

Stulz (1984) and Lessard (1990) presenting a different idea than M\&M by saying that in investing and financing decisions, there is a strong need of Corporate risk management techniques to use for hedging. The reasons which are the asymmetry of information in the market, Tax convexity schedule of the firm, External Financing, Financial Distress costs, Agency Costs and Underinvestment Problem.

Borokhovich et al. (2004) Proposed a theory that the role of outside directors with hedging is positive than inside directors. The outside directors make efficient use of derivatives to hedge the unnecessary risks. The theory is supported by others in one way or another.

In Asia the derivative market is not much organized and developed than western countries. Mian (1996) asserted that there is no strong relationship between hedging and financial distress costs and hedging, mixed evidence with tax convexity schedule and strong relationship between hedging and economies of scale.

\subsection{Hypothesis of the Study}

FX Derivatives usage is in operation in most of the non-financial companies in Pakistan. However, FX derivatives determinants which determines whether the companies use derivatives because of the financial distress costs, interest coverage ratio, Leverage etc.

Hedging policies which is important for the companies are using FX derivaitives, therefore the following hypothesis is to be developed here to determine the impact of determinants of the firm's FX derivatives.

Ho: Firms use derivatives because of higher financial distress costs.

\section{Data and Methodology}

Area of the study: In the light of the above mentioned empirical, theoretical studies and according to the hypothesis of the study, developed in the previous chapter, this study use secondary data from Pakistan Stock exchange in order to analyze the factors affecting FX derivatives usage in Pakistan. In order to analyze the Pakistani non-financial firms for using the over counter derivatives to reduce the unexpected risks in the company, 51 non-financial companies from 2010-2013 were selected in order to find out the companies using derivatives and those which are not. Data for 52 firms' has been collected from Pakistan stock exchange website, the data is in rawsecondary form and it is being analyzed to remove the banking sector and other financial firms which use the derivatives for speculation purposes. The remaining firms will be taken in to account.

\subsection{Definition of Variables}

Table-4.1. List of Variables

\begin{tabular}{l|l}
\hline Variables & Definition \\
\hline Financial distress costs & $\begin{array}{l}\text { It is measured through leverage and firm size. Where leverage is measured by } \\
\text { short term debt plus long term debt scaled by firm size. Further a firm size is } \\
\text { measured by total equity and debt of the firm. Both the proxies are measured } \\
\text { annually and these are most suitable variables to measure the financial } \\
\text { distress costs. }\end{array}$ \\
\hline $\begin{array}{l}\text { Investment opportunities and } \\
\text { internal funding }\end{array}$ & $\begin{array}{l}\text { These two variables are measured through market to book value of a firm } \\
\text { which is equal to market value/ book value and internal funding is measured } \\
\text { through liquidity and current ration. Where liquidity is measured through } \\
\text { cash and cash equivalent/firm size and current ratio equals liquid } \\
\text { assets/current liabilities. }\end{array}$ \\
\hline Interest coverage ratio & $\begin{array}{l}\text { Interest coverage ratio shows us how much is the firm ability to cover its } \\
\text { interest owed to the firm on debts. It is normally measured through the ratio } \\
\text { of earnings before interest and taxes,(in short, EBIT)/ interest expense. }\end{array}$ \\
\hline Asset growth cash flow & $\begin{array}{l}\text { The asset growth cash flow can be measured through the ratio of addition of } \\
\text { change in tangible assets plus depreciation to net income plus depreciation, } \\
\text { Representing firms' ability to convert growth options into assets in place. }\end{array}$ \\
\hline
\end{tabular}




\begin{tabular}{l|l}
\hline Profitability & $\begin{array}{l}\text { It is a ratio which shows how much a firm earns from its assets or how a firm } \\
\text { is profitable in relation to others. It is measured through the ratio of how } \\
\text { earning after interest and taxes by total assets. }\end{array}$ \\
\hline Managerial holdings & $\begin{array}{l}\text { Managerial holdings are those assets or stocks which are in possession of the } \\
\text { companies' managers. It can be options, stocks, or other valuable assets.it can } \\
\text { be measured by taking the log of managerial holdings annually. }\end{array}$ \\
\hline Foreign sales & $\begin{array}{l}\text { Sales of the company which are outside the country is to be considered } \\
\text { foreign sales. It is measured through taking the log of foreign sales. }\end{array}$ \\
\hline Tax convexity & $\begin{array}{l}\text { Tax convex schedule is for the firms whenever the profit of the firm increases, } \\
\text { the tax also increases. It is more like a progressive kind of tax on the firm. By } \\
\text { measuring the tax convexity we take binary value } 1 \text { for unused tax losses and } \\
\text { o otherwise. }\end{array}$ \\
\hline
\end{tabular}

3.2. Model Specification for Empirical Analysis

This study uses the following model by looking at different theoretical and empirical studies. However, our model is consistent with the early studies of Nguyen and Faff (2002) and Afza and Alam (2011). The designed model for this study is as under.

\section{D = f (FDC, INVO, INTF, AGC, INCV, PRI, MNGHL, FS, TXC)}

Derivative Usage in the firm is the function of financial distress costs (FDC), Investment opportunities (INVO), internal funding (INTF), Asset growth cash flow (AGC), Interest coverage ratio (INCV), Profitability (PRI), Managerial holdings (MNGHL), foreign sales (FS), and Tax convexity (TXC).

\section{$\mathrm{DEV}_{\mathrm{it}}=\alpha+\beta_{1}$ FDC $_{\mathrm{it}}+\beta_{2} \mathrm{INVO}_{\mathrm{it}}+\beta 3 \mathrm{INTF}_{\mathrm{it}}+\beta_{4} \mathrm{AGC}_{\mathrm{it}}+\beta_{5} \mathrm{INCV}_{\mathrm{it}}+\beta_{6} \mathrm{PRI}_{\mathrm{it}}+\beta_{6} \mathrm{MNGHL}_{\mathrm{it}}+\beta_{7} \mathrm{FS}_{\mathrm{it}}+\beta_{8} \mathrm{TXC}_{\mathrm{it}}+$} $\mu_{\text {it }}$

Whereas $i$ denotes cross sections and $t$ denotes time.

$\mathrm{DEV}=$ Indicates Dummies, 1 if the firm use Derivatives and o if no.

$\mathrm{FDC}=$ Indicates the financial distress cost of each firm.

$\mathrm{INVO}=$ Indicates Investment opportunities of a firm

$\mathrm{INTF}=$ Indicates Internal funding of a firm.

$\mathrm{AGC}=$ Indicates Asset Growth cash flows.

$\mathrm{INCV}=$ Interest coverage ratio

PRI $=$ Profitability of a firm

MNGHL $=$ Managerial holdings of a firm

$\mathrm{FS}=$ Foreign sales

$\mathrm{TXC}=$ Tax convexity

The second model shows the interaction of between firms' FX derivatives usage and its investment and financing policies following Mian (1996); Lin et al. (2008); Bartram et al. (2009) and Afza and Alam (2011).

Whereas Model 2 suggests that there is an interface between the firm's corporate FX derivatives usage and its investment and financing policies following Afza and Alam (2011); Lin et al. (2008) and Bartram et al. (2009):

Whereas:

$$
\mathrm{DEV}_{\mathrm{it}}=\alpha+\beta_{1} \text { Leverage }_{\mathrm{it}}+\beta_{2} \text { DIVP }_{\mathrm{it}}+\beta 3 \mathrm{LIQ}_{\mathrm{it}}+\varepsilon_{\mathrm{it}}
$$

LEVRG $=$ Represents the ratio of total debts over total assets.

$\mathrm{DIVP}=$ depicts the dividend payout ratio which equals to dividend per share by earnings per share.

Liquidity= Liquidity is how you can easily convert your assets into cash which equals here, current assets minus inventory to current liabilities, representing liquidity.

Econometric Techniques used in this study:

Since this study deals with Binary Dependent variable Logistic Regression model will be applied to detect the factors that affect the derivatives usage of non-financial listed firms of Pakistan to hedge foreign exchange exposure in case of Pakistan for the period of 2010-2013. The motive behind applying Logistic Regression Model over Linear Probability Model (LPM) is that LPM considered that the probability values of 0-1 will always lie between $O$ and 1 but this is not the case it might exceed 1 sometimes causing problems. Moreover, the error term may not be normal and heteroscedasticity problem may also exist while having binary dependent variable (Econometrics by Example, Gujarati and Porter (1999).

\section{Results and Discussions}

In order to determine the factors which affects the firms' derivatives usage and its factors impact in the interaction with firm investing and financing policies. This study applied different statistical and econometric tests. The basic purpose of these tests are to check the effect of financial distress costs, underinvestment problem, tax convexity, profitability, managerial ownership and foreign exchange exposure on firms' decision to use FX derivatives instruments for hedging purposes. This section shows us the methods and results interpretations which is about the firms' derivatives usage.

\subsection{Descriptive Analysis}

Table 5.1 shows the descriptive statistics of users and non-users. The independent variables of both users and non-users have been analyzed, its mean and standard deviation is also given in the table. The results shows that users of financial derivatives have higher financial distress costs which is 0.44 as compared to non-users which is 0.46. The leverage for the users is also high as compared to non-users, for the users it is .5514 while for the nonusers it is .4779. While some researchers find it inconsistent with the financial distress costs, the results in this research is consistent of leverage with financial distress costs. It means that those firms which are financially distressed are also have a high debited firms. The firms in these situations uses foreign exchange financial derivatives. Another important variable is the interest coverage ratio which is also consistent and related with the financial distress costs. It is parallel to it which shows that financially distressed firms are unable to pay interest 
expenses on debts which pressurized the companies to resort to the foreign exchange derivatives in Pakistan. In this the Interest coverage ratio is 6.59 while non-users have 8.35 , the users are incompetent due to the financial constraints and therefore they employ financial hedging instruments. United with the Pakistani market and its derivative situation which is non-existed while the companies' especially big companies employ hedging instruments. It can also be observed here that Firm size of users is larger than Non-users, i.e. Users(10.435) while non users 9.88 which shows us that mostly larger firms in Pakistan employs the hedging instruments to mitigate the risks of the firm. By taking up sales in foreign into account, it shows that users have higher currency exposure in foreign countries and thus shows higher value which is 6.70 while the non-users have less exposure, therefore non-users don't employ hedging instruments. Using the dummy variable for tax losses on Pakistani firms, Satisfactory with the results which shows that users who are using financial derivative instruments for hedging have 50 percent tax losses as compared to non-users who have only 45 percent. According to the agency theory which shows the agency cost of equity, that managers having higher stake in equity will employ the hedging instruments but the results are quite contradictory here which shows that managerial ownership of firms are lesser than those of non-users. Nonetheless, the results are not statistically significant here.

It is rational here to say that Profitability and liquidity both are consistent with the theory, the companies adopting hedging techniques have higher profitability and higher than companies that don't use derivative or hedging instruments. Liquidity is 1.311 for the users while for the non-users it is .789. The ROA for the users is .853 while for the non-users it .11. Moreover, it shows that the firms are not quite liquidity constrained firms as the non-users are. The last variable is dividend payout ratio, it is contradictory here with the theory of substitutes of hedging which shows that firms with lower dividend payout ratio are considered the users of hedging instruments, Supporting the financial distress cost hypothesis which explains that firms with lower dividend are financially distressed and therefore they employ hedging instruments to support the highly invariable cash flows they have, to reduce the unpredictability of the cash flows and to mitigate the risk of the company. Therefore, the companies of users of derivatives instruments have $.28 \%$ payout ratio while the non-users have $41 \%$ payout ratio.

Table-5.1. Univariate Analysis

\begin{tabular}{l|l|l|l|l}
\hline Variables & User (107) & Non-User (95) & User (SD) & Non-User (SD) \\
\hline FDC & 0.44034 & 0.46972 & & \\
\hline LEV & .551470 & .477962 & .529957 & 5803596 \\
\hline INC & 6.59532 & 8.35340 & 5.3520 & 19.5300 \\
\hline FSIZE & 10.4350 & 9.88785 & .913120 & .902300 \\
\hline LFS & 6.738318 & 5.95708 & 4.40697 & 4.40685 \\
\hline TAX & .5046730 & .452632 & .5023310 & .5003918 \\
\hline MNGRL & 5.574074 & 5.63861 & 3.48616 & 3.525373 \\
\hline QR & 1.311239 & .789851 & 3.923493 & .6466414 \\
\hline DP & .2482370 & .419206 & 3271818 & 2.032260 \\
\hline Source & & &
\end{tabular}

\subsection{Correlation Matrix}

In the correlation table, two groups are being analyzed, in group A, all the investment and financing variables are excluded and the rest of the operating characteristics are presented in group of the correlation matrix table. It explains that large firms which uses hedging instruments have lower managerial ownership, have higher ability to convert its assets into cash to grow more. It also propounds that firms having higher interest coverage ratio, which is related to those firms who are using FX derivatives. These all are consistent with the theory. In addition to this, Firms such as higher financially distressed have lower interest coverage ratio as it is very difficult for them to fulfill their obligations. Group B reports about the correlation coefficients which is for firms' endogenous policies that stand back the theory that financially constrained Companies are further likely to take debt for their investments.

Group A

Table-5.2. Correlation Matrix

\begin{tabular}{l|l|l|l|l|l|l|l|l}
\hline & FDC & INC & FS & ROA & MNGRL & LFS & TC & AGCF \\
\hline FDC & 1 & & & & & & & \\
\hline INC & -0.01248 & 1 & & & & & & \\
\hline Firm Size & 0.25121 & 0.05353 & 1 & & & & & \\
\hline ROA & 0.97732 & 0.00246 & -0.21817 & 1 & & & & \\
\hline MNGRL & 0.09951 & -0.00036 & 0.252728 & -0.10364 & 1 & & & \\
\hline LFS & 0.09821 & -0.00470 & 0.202569 & -0.07586 & 0.04589 & 1 & & \\
\hline Tax Convexity & 0.06736 & -0.08136 & -0.17273 & -0.08537 & -0.13408 & -0.10877 & 1 & \\
\hline AGCF & 0.00740 & -0.01683 & 0.06839 & 0.00824 & -0.01621 & 0.08637 & 0.08681 & 1 \\
\hline So
\end{tabular}

Source: Authors own Calculation

Group B

Table-5.3. Correlation for second Model

\begin{tabular}{l|l|l|l}
\hline & DPR & Liquidity & Lev \\
\hline DPR & 1 & & \\
\hline Liquidity & 0.006985 & 1 & \\
\hline Leverage & 0.003832 & -0.00855 & 1 \\
\hline Source: Authors own Calculation & & \\
\hline
\end{tabular}

\subsection{Empirical Results}

In the following Table 5.4, Logit model is used to identify the document the factors that determine the company's decision to use Foreign Exchange derivatives for mitigating the risk exposure of the firm. Data of these 
variables were estimated which is given of two models, the first model is without the financing and investing variables while the model two is related to financing and investing policies of the firm. According to the estimated results of model 1, it explains that financial distress costs, interest coverage ratio, firm size, Asset growth over cash flow, profitability and foreign sales have signs which are in relation to the predicted signs from the previous literature. Two variables which are managerial holdings and tax convexity which shows from the model 1 that they are not consistent with the theory. It shows that those companies which are financially distressed and have not much ability to cover interest of the debt holders employ derivatives of foreign exchange to hedge risks of firm exposure to deter the behavior of debt holders. Managerial holdings is not consistent with the theory because most of the directors prefer to have value creation activities which obviously the hedging instruments techniques to stabilize the cash flows of the company, whereas smaller companies cannot afford to have such techniques available for value creation because of the smaller managerial holdings. Afza and Alam (2011) have also found a negative relationship between managerial holdings and usage of derivatives. Similar is the case of tax losses in this regard, Afza and Alam (2011) have found negative relation between tax losses and derivative usage of firms. It is believed that tax losses of firms which are able to reduce income gains, but are not able that much to affect firms, also the tax benefits are not that much which should cover the company financial position and are lesser than the income gains, therefore the companies don't use derivatives with tax losses. Empirical results are also similar to the following of earlier literature of Afza and Alam (2011) and Fok et al. (1997) which shows that leverage depicts a significant negative role on firms' usage of derivatives instruments for hedging. It is believed that high debt firms are going to be more financially distressed firms and therefore will not be able to pay interest to the debt holders are less likely to use to debt and therefore does not employ the foreign exchange derivative instruments to mitigate the risks of the company. Lastly, the dividend payout ratio which shows a negative relation with the companies' derivative usage and for that matter supports the theory of derivatives. It is believed that most of the companies which have highly volatile cash flows are likely to cut dividends and employ the hedging instruments. Commonly, Companies which are larger in size, having higher financial distress costs, having lower leverage, dividend payout ratio, higher managerial stake in the company, profitability and liquidity, and tax convexity are more likely to use foreign exchange derivatives for hedging to reduce the company's exposure in the market.

Table-5.4. Logistic Regression Analysis Results
Model-1 \begin{tabular}{l|l|l|l|l} 
Model-2 \\
Logistic Regression
\end{tabular}

Note: ${ }^{* * *}, * *$ and $*$ indicates level of significance at $1 \%, 5 \%$ and $10 \%$ correspondingly.

\section{Conclusion}

The study explains and extends the current literature on the corporate derivatives and its usage in the MNC's and national level companies. This study is about the current hedging policies and its very use in the organization. How the companies mitigate the risks of exposure in the market and how they are hedged is all the possibilities of these corporate risk management techniques. It contributes up to much extent in the companies risk exposure in developed and in developing countries. Even countries like United States, Australia, Canada, Spain, England, Japan and in developing countries like India, Brazil benefit from the usage of derivatives in the company. It has a significant role as can be witnessed from the existing literature to the company but more importantly to the overall performance of the economy.

Almost all large size companies are using derivatives to mitigate the risk in Pakistan, even though, the companies have not the opportunity of the derivative market in Pakistan, especially the organized exchange of the derivatives not even over the counter as well. Besides these benefits, there are certain factors which affects the performance of the companies stance whether to use derivatives or not. The key issues by Pakistani firms not only in Pakistan, but other developing countries that they don't have the facility to hedge the risk in their own country but to do it in the developed countries markets and that is over the counter markets. The role of hedging instruments is a significant one in this today socio-political countries because of the political risks, technological risks and economical risks.

The importance of derivatives usage in a firm to hedging risk and its impact on a firm is considerably studied by the researcher and academia in the developed countries, keeping in mind the importance of derivatives in the developed countries, similar efforts have not been made in the developing countries and on over the counter markets. However, this study is conducted in Pakistan by determining the factors which influence the firms' decision to use FX derivatives as an instrument for the hedging purposes. The study is steered on Pakistan stock exchange non-financial companies by using the sample of 51 companies in which the users of derivatives were 27 companies while non-users were 24. More over the results of this study shows that those firms which are users of derivatives are mostly financially distressed and are high debited firms which is consistent with the theory of Stulz (1984) that firms will tend to use hedging instruments which are financially distressed and have larger debts to pay. 
Moreover, it is also being analyzed that financially distressed firms have lower interest coverage ratio is also involved in the hedging techniques. Contradictory to these are the profitability and liquidity which is also good of the non-financial companies of Pakistan stock exchange but not that much statistically significant to the results of non-users non-financial companies. Correlation matrix in two groups were also analyzed of the variables which affects the firms' decision to use derivatives. The other variables such as the tax convexity is also in contradiction to the existing theory of risk management. It is also being analyzed that Pakistani non-financial listed firms in the Pakistan stock exchange which are highly financially distressed firms, lower interest coverage ratio, Profitability and foreign sales are consistent, with the theory in terms of path and magnitude. the case of tax losses in this regard, Afza and Alam (2011) have found negative relation between tax losses and derivative usage of firms. It is believed that tax losses of firms which are able to reduce income gains, but are not able that much to affect firms, also the tax benefits are not that much which should cover the company financial position and are lesser than the income gains, therefore the companies don't use derivatives with tax losses.

Empirical results are also similar to the following of earlier literature of Afza and Alam (2011) and Fok et al. (1997) which shows that leverage depicts a significant negative role on firms' usage of derivatives instruments for hedging. It is believed that high debt firms are going to be more financially distressed firms and therefore will not be able to pay interest to the debt holders are less likely to use to debt and therefore does not employ the foreign exchange derivative instruments to mitigate the risks of the company. Lastly, the dividend payout ratio which shows a negative relation with the companies' derivative usage and for that matter supports the theory of derivatives. It is believed that most of the companies which have highly volatile cash flows are likely to cut dividends and employ the hedging instruments. The results estimated for the foreign exchange derivatives for Pakistani firms will make them able to understand its policy guidelines which certainly will lead to these firms usage. The optimal usage of FX derivatives will enable them to use FX derivatives' which will certainly enable them to smooth their cash flows by reducing the opportunistic behavior of the stake holders such as shareholders and debt holders. This will ultimately reduce the agency and equity costs of the company.

\subsection{Policy Recommendations}

1) Most of the non-financial firms are not aware or are risk averse. They will invest in collateralized bonds or debentures which is a good sign of investment for them, even they will take a loan from banks but will not consider the derivatives which is considered as a legalized gambling in the world. Government should start the derivative exchange which must be like Pakistan stock exchange, an organized market where futures, forwards, swaps, options and likewise contracts could be traded. This will help much better for the economy and the companies will gain confidence in such investments to hedge their risks and perform better

2) In order to be aware of the market situations and this lack of information about derivatives in Pakistani market must come to an end. The authors for the future research must focus upon the advantages of the risk management techniques and alike to spread its positive picture among the companies and the stake holders.

\section{References}

Afza, T. and A. Alam, 2011. Corporate derivatives and foreign exchange risk management: A case study of non-financial firms of Pakistan. Journal of Risk Finance, 12(5): 409-420.

Aretz, K., S.M. Bartram and G. Dufey, 2007. Why hedge? Rationales for corporate hedging and value implications. Journal of Risk Finance, $8(5): 434-449$.

Bartram, S.M., 2000. Corporate risk management as a lever for shareholder value creation. Financial Markets, Institutions \& Instruments, 9(5): 279-324.

Bartram, S.M., G.W. Brown and F.R. Fehle, 2009. International evidence on financial derivatives usage. Financial Management, 38(1): 185206.

Bessembinder, H., 1991. Forward contracts and firm value: Investment incentive and contracting effects. Journal of Financial and Quantitative Analysis, 26(04): 519-532.

Bessembinder, H. and P.J. Seguin, 1990. Futures trading, liquidity, and stock price volatility. Mitsui Life Financial Research Center, School of Business Administration, University of Michigan.

Borokhovich, K.A., K.R. Brunarski, C.E. Crutchley and B.J. Simkins, 2004. Board composition and corporate use of interest rate derivatives. Journal of Financial Research, 27(2): 199-216.

Campbell, T.S. and W.A. Kracaw, 1987. Optimal managerial incentive contracts and the value of corporate insurance. Journal of Financial and Quantitative Analysis, 22(03): 315-328.

Cutler, D.M., J.M. Poterba and L.H. Summers, 1989. International evidence on the predictability of stock returns. Unpublished Manuscript, MIT.

DaDalt, P., G.D. Gay and J. Nam, 2002. Asymmetric information and corporate derivatives use. Journal of Futures Markets, 22(3): 241-267.

Dolde, W., 1993. The trajectory of corporate financial risk management. Journal of Applied Corporate Finance, 6(3): 33-41.

Fazillah, M., T.S. Hui and N.A. Azizan, 2008. The relationship between hedging through forwards, futures \& swaps and corporate capital structure in Malaysia. Second Singapore International Conference on Finance.

Fok, R.C., C. Carroll and M.C. Chiou, 1997. Determinants of corporate hedging and derivatives: A revisit. Journal of Economics and Business, 49(6): 569-585

Froot, K.A., D.S. Scharfstein and J.C. Stein, 1993. Risk management: Coordinating corporate investment and financing policies. Journal of Finance, 48(5): 1629-1658.

Géczy, C., B.A. Minton and C. Schrand, 1997. Why firms use currency derivatives. Journal of Finance, 52(4): 1323-1354.

Graham, J.R. and D.A. Rogers, 2002. Do firms hedge in response to tax incentives? Journal of Finance, 57(2): 815-839.

Graham, J.R. and C.W.J. Smith, 1999. Tax incentives to hedge. Journal of Finance, 54(6): 2241-2263.

Gruber, M.J. and J.B. Warner, 1977. Bankruptcy costs: Some evidence. Journal of Finance, 32(2): 337-347.

Guay, W. and S.P. Kothari, 2003. How much do firms hedge with derivatives? Journal of Financial Economics, 70(3): 423-461.

Gujarati, D.N. and D.C. Porter, 1999. Essentials of econometrics.

Haushalter, G.D., 2000. Financing policy, basis risk, and corporate hedging: Evidence from oil and gas producers. Journal of Finance, $55(1)$ : $107-152$.

Horng, Y.S. and P. Wei, 1999. An empirical study of derivatives use in the REIT industry. Real Estate Economics, $27(3): 561$.

Howton, S.D. and S.B. Perfect, 1998. Currency and interest-rate derivatives use in US firms. Financial Management, 27(4): $111-121$.

Jalilvand, A., 1999. Why firms use derivatives: Evidence from Canada. Canadian Journal of Administrative Sciences/Revue Canadienne des Sciences De l'Administration, 16(3): 213-228.

Kedia, S. and A. Mozumdar, 2003. Foreign currency-denominated debt: An empirical examination. Journal of Business, 76(4): 52 1-546. 
Lang, L.H. and R. Stulz, 1992. Contagion and competitive intra-industry effects of bankruptcy announcements: An empirical analysis. Journal of Financial Economics, 32(1): 45-60.

Lessard, D.R., 1990. Global competition and corporate finance in the 1990s. Journal of Applied Corporate Finance, 3(4): 59-72.

Lin, C.M., R.D. Phillips and S.D. Smith, 2008. Hedging, financing, and investment decisions: Theory and empirical tests. Journal of Banking \& Finance, 32(8): 1566-1582

Mayers, D. and J.C.W. Smith, 1982. On the corporate demand for insurance. In foundations of insurance economics. Netherlands: Springer. pp: 190-205.

Mayers, D. and J.C.W. Smith, 1990. On the corporate demand for insurance: Evidence from the reinsurance market. Journal of Business: 1940.

Mian, S.L., 1996. Evidence on corporate hedging policy. Journal of Financial and quantitative Analysis, 3 1(03): 419-439.

Miller, M.H. and F. Modigliani, 1958. The cost of capital, corporation finance and the theory of investment. American Economic Review, 48(3): 261-297.

Muller, A. and W.F. Verschoor, 2007. Asian foreign exchange risk exposure. Journal of the Japanese and International Economies, 21(1): 1637.

Myers, S.C., 1977. Determinants of corporate borrowing. Journal of Financial Economics, 5(2): 147-175.

Nguyen, H. and R. Faff, 2002. On the determinants of derivative usage by Australian companies. Australian Journal of Management, 27(1): $1-24$.

Nguyen, H. and R. Faff, 2003. Further evidence on the corporate use of derivatives in Australia: The case of foreign currency and interest rate instruments. Australian Journal of Management, 28(3): 307-317.

Purnanandam, A., 2008. Financial distress and corporate risk management: Theory and evidence. Journal of Financial Economics, 87(3): 706739.

Rawls, S.W. and C.W. Smithson, 1990. Strategic risk management. Journal of Applied Corporate Finance, 2(4): 6-18.

Schiozer, R.F. and R. Saito, 2009. The determinants of currency risk management in Latin American nonfinancial firms. Emerging Markets Finance and Trade, 45(1): 49-71.

Securities \& Exchange Commission of Pakistan (SECP), 2006. International Affairs, Communication \& Coordination (IACC) Department

Smith, C.W. and R.M. Stulz, 1985. The determinants of firms' hedging policies. Journal of Financial and Quantitative Analysis, 20(04): 391405.

Stulz, R.M., 1984. Optimal hedging policies. Journal of Financial and Quantitative Analysis, 19(02): 127-140.

Weiss, L.A., 1990. Bankruptcy resolution: Direct costs and violation of priority of claims. Journal of Financial Economics, 27(2): 285-3 14.

\section{Bibliography}

Gay, G.D. and J. Nam, 1998. The underinvestment problem and corporate derivatives use. Financial Management: 53-69.

Citation | Numan Khan; Khurshid Ali; Alina Kiran; Riaqa Mubeen; Zeeshan Khan; Nasir Ali (2016). Factors that Affect the Derivatives Usage of Non-Financial Listed Firms of Pakistan to Hedge Foreign Exchange Exposure. Journal of Banking and Financial Dynamics, 1: 9-20.

\section{History:}

History:

Received: 13 October 2016

Revised: 15 November 2016

Accepted: 21 November 2016

Published: 26 November 2016

Licensed: This work is licensed under a Creative Commons

Attribution 3.0 License $(\mathrm{cc})$

Publisher: Eastern Centre of Science and Education
Acknowledgement: All authors contributed to the conception and design of the study.

Funding: This study received no specific financial support.

Competing Interests: The authors declare that they have no conflict of interests.

interests. Transparency: The authors confirm that the manuscript is an honest, accurate, and transparent account of the study was reported; that no vital features of the study have been omitted; and that any discrepancies from the study as planned have been explained.

Ethical: This study follows all ethical practices during writing.

Eastern Centre of Science and Education is not responsible or answerable for any loss, damage or liability, etc. caused in relation to/arising out of the use of the content. Any queries should be directed to the corresponding author of the article. 